\title{
The Role of Law in European Monetary Integration : A Critical Reconstruction and a Response to Klein
}

\section{Frerichs, Sabine}

2021-05-24

Frerichs, S \& Losada , F 2021, ' The Role of Law in European Monetary Integration : A Critical Reconstruction and a Response to Klein ' , Global perspectives , vol. 2 , no. 1 , 24131 . https://doi.org/10.1525/gp.2021.24131

http://hdl.handle.net/10138/332215

https://doi.org/10.1525/gp.2021.24131

acceptedVersion

Downloaded from Helda, University of Helsinki institutional repository.

This is an electronic reprint of the original article.

This reprint may differ from the original in pagination and typographic detail.

Please cite the original version. 
The Role of Law in European Monetary Integration: A Critical Reconstruction and a Response to Klein Sabine Frerichs and Fernando Losada

This is the accepted author manuscript of the article published in final version as:

'The Role of Law in European Monetary Integration: A Critical Reconstruction and a Response to Klein', Global Perspectives, Vol. 2, Issue 1, 2021

https://doi.org/10.1525/gp.2021.24131

\begin{abstract}
In an article recently published in this journal, Steven Klein revised Karl Polanyi's conceptualization of the relation between economy and society, and adapted it to the post-crisis European context. His reconstruction put emphasis on the redemocratization potential of trade unions and central banks against the pernicious effects of the commodification of labor and money on the European level. While Klein's approach is without doubt very insightful and original, we think that some of his claims either deserve discussion or require closer elaboration. This concerns the conceptual approach of setting Polanyi against Habermas as well as the critique of the role of law in the integration process. As to the latter, we think that further contextualization is due to appreciate changing historical contexts and layers of European integration. With the objective in mind to enrich Klein's analysis, we first propose a way to reconcile, against what Klein suggests, Polanyian and Habermasian understandings of law and money. This theoretical background will help us, second, to explore in detail the differences between market and monetary integration, and in particular the role that law plays in each of these politico-economic constellations. Based on this we will, third and final, explain how the interaction of public and private law in the context of post-crisis European integration further promotes the process of commodification, and how the configuration of law in market and monetary integration currently prevents trade unions and central banks from exerting the re-democratizing potential that Klein's assigns to them.
\end{abstract}

Keywords: monetary integration, Polanyi, Habermas, law, money

\title{
I. Introduction: a contextual approach to the law of European integration
}

This article forms part of an interdisciplinary conversation between legal scholars and social scientists on the state of European integration after the Eurozone crisis. A common denominator among the contributors to this debate is their law-in-context approach in which emphasis is laid on how social theoretical perspectives 
may help to illuminate legal and institutional developments, critical junctures in the integration process, and fault lines in the European polity of today. Like other contributions published in this journal, we develop our ideas and arguments in relation to the broader conversation, which has continuously been organized by Christian Joerges and, especially, in response to the selected target article by Steven Klein (2020a) on "European Law and the Dilemmas of Democratic Capitalism".

Our comments on Klein's article revolve around the implications of a fundamental distinction, which appears in his argumentation but has not been exploited to its full potential: namely, between 'market integration' and 'monetary integration'. In our understanding, this is a significant distinction that helps to reveal key differences in the relation between economy, politics, and law in these two constellations. Based on Polanyi's ideas, Klein offers a number of valuable insights in this regard, but he does not systematically distinguish between market and monetary integration. This has implications for his account of the legal dimension of European integration. For Klein (2020a, 2), it is "the telos of the single market that informs European law", in which regard the law of monetary union does not seem to make a difference. However, as we will demonstrate, one arrives at a more differentiated picture of the law of European integration by separately addressing these two layers of integration.

Our approach relies on a contextual understanding of law, for which it is equally important to take the historical dimension of European integration into account: we understand it as a process unfolding over time. The development and consolidation of market integration and monetary integration, which now coexist and influence each other, took place at different points in time and in different contexts, with their overlapping only occurring relatively recently. We thus think that the study of the two constellations necessarily has to differentiate between the political and economic contexts to which they relate - an aspect sometimes missing in Klein's analysis. Distinguishing between market and monetary integration allows highlighting of two aspects that, beyond their specific interest for lawyers, can improve the general understanding of the dynamics at work in European integration. The first is the role assigned to law within each of the two constellations or, put into different words: what is the concrete relation of law with regard to economy and politics in market versus monetary integration? A subsequent issue is what type of law results from, or predominates, in each constellation.

The contextual and historical approach is also relevant in considering, appreciating, and criticizing different authors' ideas about the relation between law, economy, and politics in the European context. While Polanyi's ideas, written before the inception of the European integration process, can be interpreted as a coherent whole and adapted to and contrasted against the current circumstances without running into internal inconsistencies, a more nuanced analysis is required in the case of authors contemporary to the evolution of European market and monetary integration, such as Habermas. Their statements and ideas, which may have referred to one specific historical context only, have to be carefully considered when adapted to the current state of development of European integration. While our analysis of the role of law in European integration is inspired by Habermas's discourse theory of law, our interpretation is tailored to the changing constellations of the European integration process.

Moreover, since Klein is quite critical with regard to Habermas's conception of law, which we consider useful as a pivot for a critical reconstruction of legal developments in the European context, our comments will also touch on more conceptual questions. In fact, Klein sees a problem with Habermas's discourse-theoretical approach not only in the conception of law as a mediator between systems and the lifeworld but also in the conception of the economic system as governed by the medium of money, which law can only regulate from 
without. That way, Habermas's functionalist view of money would 'overburden' the law (Klein 2020b, 3-4). This is something Klein seeks to cure by bringing in Polanyi's perspective of money as a fictitious commodity as a conceptual entry point for democratic regulation within the economic sphere. As much as we sympathize with exploring Polanyian perspectives on European integration, we do not think that this has to lead to a face-off between the two approaches but, rather, that they can also be synergetically combined.

In the following, we will first point out complementarities between Polanyi's and Habermas's approaches to modern society (section II), before turning to a more detailed analysis of the role of law in market vs monetary integration (section III). The last part (section IV) addresses some concrete issues raised by Klein's approach regarding the law of monetary integration and the re-democratization of money and labor.

\section{Law and money as contested: combining the ideas of Polanyi and Habermas}

The role of law differs in the contexts of market integration and monetary integration. This is key in understanding the dynamics of European integration today. Law may still be considered as a means of integration, but money in its different forms has likewise become a driving force. The implications of the European currency go beyond facilitating market exchange across borders and include imposition of a new fiscal contract on the members of what can increasingly be seen as a 'community of debt'.

It is this intertwinement of law and money as a means of European integration which requires scholarly attention and calls for a theoretical framework that can shed light on it. We largely agree with Klein (2020a) as the author of the target article, and with Joerges (2021) as his inspirer and interlocutor in this venture, that conceptual support can be found at the juncture of critical legal theory and critical political economy, with Habermas and Polanyi being central reference points. However, we see less need than Klein in pitting the one against the other but, rather, more potential in indeed creating a synthesis between the two approaches, combining their critical insights into the ambiguities of law and money, respectively.

In a nutshell, Klein's (2020a) outline of a critical theory in this journal, which builds on his previous piece on "The power of money" (Klein 2020b), finds the democratization potential of law overemphasized and the democratization potential of money underdeveloped in Habermas's theory, and resorts to Polanyi's understanding of fictitious commodities (land, labor, money) as an entry point for possibilities of democratic reorganization inside the economic sphere. His emphasis is on interactions between labor and money in the European context, but the role of law in general and in monetary union is also addressed.

In contrast, we would highlight - with Habermas - the tensions inherent in the law and - with Polanyi - the tensions inherent in money as (interdependent) means of societal integration and of European integration in particular. We think that the two approaches can well be linked based on their commonalities and complementarities, and that taken together they promote a more comprehensive understanding of the interactions between law and money in contemporary capitalism and European integration, in particular.

\section{II.1 The tension inherent to law: learning from Habermas}

As to the role of law in societal integration, we can start from discourse-theoretical perspectives. As first developed by Habermas and further specified by Joerges and others, the discourse theory of law draws on the democratic ideals from which law derives its legitimacy and specifies the preconditions of deliberative practices in social reality. Law is conceived as "a social category of mediation between facts and norms" (Habermas 1996, 1), which entails a distinctive vision of integration through law (Frerichs and Losada 
forthcoming). Inasmuch as law derives its authority from a deliberative process that furthers rational agreement in controversial political issues, legality and legitimacy are intricately linked (cf. Habermas 1996, 32-34).

We agree that an understanding of law as a means of societal integration requires combining internal and external, participant and observer perspectives (Kelsen 2002; Hart 1961). What is needed is not only an account of law's functional or factual power in terms of how it shapes, or even imposes, certain patterns of behavior, but also an insight into the underlying value relations (Weber 1949), normative structures, and perceptions of right and wrong, which make legal arguments resonate and the legal order experienced as legitimate (or not).

This understanding is also evident in Joerges's approach, which decries the 'schism' between facts and norms that can be observed in European studies and beyond (Joerges and Kreuder-Sonnen 2017, 138). To ameliorate this, he calls on legal scholars to take the economy seriously and social scientists to take the law seriously (Joerges 2016, 300). For us, this also explains his impetus to combine critical legal theory with critical political economy, drawing on Habermas's and Polanyi's approaches. In his recent writings, Joerges constantly invokes "Polanyi's economic sociology [...] as a sociological basis" for his own conception of conflicts-law constitutionalism (Joerges 2011, 415; cf. Joerges, Stråth and Wagner 2005; Joerges and Falke 2011).

Klein is sympathetic with Joerges's approach but questions Habermas's social theory from which it derives. He criticizes Habermas for crediting (only) law with the ability to bridge the gap between economic and administrative systems and the rationalized lifeworld. For Klein, this account of law's mediating function between systems and lifeworld implies a "restriction of political interaction to the medium of law" (Klein 2020 b 3), which would make it difficult to think of alternative ways to politicize and democratize the economic system from within. While he finds the democratization potential of law overemphasized in Habermas's works, a related charge is that Habermas's conception of the economic system is far too narrow and that especially his understanding of money is one-sided and economistic.

Before we take up this second criticism, we would like to indicate that Habermas's discourse theory of law already has many parallels with Polanyi's institutional theory of the economy (Polanyi 1957a), and is not really counterposed to the latter. In fact, Habermas's work already includes elements of economic sociology (Beckert 2009), and his account of 'marketization' - the colonization of the lifeworld by the imperatives of the market - could even be considered as a 'further development' of Polanyi's framework (Ebner 2015).

To illustrate, both theories combine notions of 'social integration' in the lifeworld of actors with notions of 'systems integration' in a functionally differentiated society (Lockwood 1992). According to Habermas, "[m]odern societies are integrated not only socially through values, norms, and mutual understanding, but also systemically through markets and the administrative use of power" (Habermas 1996, 39). For Polanyi, social integration rests in the 'social embeddedness' of markets (cf. Olofsson 1995, 72-113), which can be contrasted with the relative 'disembeddedness' of markets in the market society, where the 'economic system' is allowed "to function according to its own laws" (Polanyi 1957b, 57). If markets come to dominate society as a whole, social integration is supplanted by systemic forces: "Instead of economy being embedded in social relations, social relations are embedded in the economic system." (Polanyi 1957b, 57). 
What Habermas describes as the interplay between systems and lifeworld, Polanyi substantiates in terms of the imperatives of the economic system (laissez faire) and a protectionist social reaction: the so-called 'double movement' (Polanyi 1957b, 132). The countermovement is underpinned by popular conceptions of justice and beliefs in legitimacy. In this regard, Polanyi proves to be a "theoretician of the moral economy" (Hann 2010, 196; cf. Jessop and Sum 2019). While traditional moral economies have been defended by appeal to justice, but not (yet) in the language of rights (Thompson 1991, 350; cf. Thompson 1971), this vocabulary is standard in modern societies to express individual demands and collective protests. Not surprisingly, the 'system of rights' also lies at the core of the discourse theory of law (Habermas 1996, ch. 3).

As to the law as such, this is not overlooked in Polanyi's work, but not analyzed systematically (Frerichs 2016). At the same time, an institutional theory of the economy naturally has a place for legal institutions, which can be specified in a Polanyian spirit (Frerichs 2019). Law 'institutes' the market (cf. Polanyi 1957a). At the same time, law can also become subject to market forces and acquire properties of a 'fictitious commodity' (cf. Polanyi 1957b, ch. 6). 'Law as commodity' and 'law as institution' can be marked as opposite tendencies which law can develop in modern political economies. This links Polanyi back to Marx and forward to Habermas. It also resonates with the work of other political economists who can be credited with taking law seriously (e.g., Commons 1924).

\section{II.2 The tension inherent to money: learning from Polanyi}

Overall, Habermas and Polanyi seem highly compatible in their views of modern society, albeit their approaches accentuate different aspects in the continuum of law, economy, and society. Klein takes a different stance in contrasting the two. Indeed, he finds significant shortcomings in how the economy is conceived in Habermas's work compared to Polanyi's approach. His argument centers on their respective conceptions of money and its role in the political economy.

Klein (2020a, 3; 2020b, 3-4) takes issue with Habermas's conception of money as a medium of exchange, which he identifies as a very limited and economistic understanding of money that, in Polanyi's terms, could be equated with money as a commodified means of market exchange. This narrow understanding of money would neglect the democratization potential that comes to the fore when the payment function of money is considered as well, or its quality as a promise to pay in a network of social relations, which is backed by fiscal policies and central banking. This possibility of democratic oversight of the generation and distribution of credit is precisely what Klein aims to highlight in Polanyi's work.

Polanyi's notion of money as a fictitious commodity combines elements of 'commodity theories of money' and 'credit theories of money' (Hart 1986). Even though Polanyi's concept of money is substantially richer than that of Habermas, we think that it is mistaken to consider Habermas as a representative of a commodity theory of money. Drawing on sociological systems theory, Habermas introduces money as a symbolically generalized medium of exchange, which condenses an otherwise highly complex sequence of communications (cf. Habermas 1987, 165 and 261-266). Money is not the only 'steering medium' that reduces information this way. Indeed, law, or the code of legality, can also be considered as such (cf. Habermas 1987, 365).

Klein acknowledges this systems-theoretical background but still insists on charging Habermas with an economistic concept of money, which "mirrors the commodity view of money" (Klein 2020b, 11). We think that generalizing certain properties from money as a medium of exchange is not the same as narrowing 
money down to its functions in 'self-regulating' markets (cf. Habermas 1987, 264-265). In the target article, Klein $(2020 a, 3)$ even aligns Habermas's concept of money as a generalized medium of communication, with Hayek's understanding of markets as an information-aggregating mechanism working through price signals. Again, we think that this is not very much to the point, since Habermas's notion of money does not imply anything like a private-law society with minimal state intervention, which is, however, insinuated in Hayek's bottom-up conception of a market society (Hesselink 2010, 127-128).

We think that a smarter move would be to investigate parallels between the means, or medium, of law and the means, or medium, of money alongside both Habermas's and Polanyi's conceptual frameworks. As indicated above, Polanyi's ideas about the interrelations of economy and society can well be enriched with a conception of law that also exposes its inherent ambiguities, as discussed in the discourse theory of law. Analogically, Habermas's ideas about the role of law in integrating capitalist society could be complemented by a similar account of the role of money as a means of integration, which starts from the ambiguities of money as a fictitious commodity, as highlighted in Polanyi's approach.

Polanyi discussed money both as an 'embedding institution' (Polanyi 1957a, 32) and a 'fictitious commodity' (Polanyi 1957b, 72). With regard to the 'long' nineteenth century, the international gold standard is presented as "an attempt to commodify money" (Saiag 2014, 563), since an imbalance of payments between two countries would automatically be settled by gold movements. In contrast, the generation of purchasing power "through the mechanism of banking or state finance" (Polanyi 1957b, 72) highlights the contingency and manageability of credit and debt in domestic contexts. The resulting tension has been captured in terms of a distinction between 'national credit money' and 'international commodity money' (Sum and Jessop 2013, 289-292).

Just as with law, it is the genesis of money before and outside the market - in social relations, mutual commitments, and the organizing power of the state - which exposes its 'original' and non-commodified character: as a collective fiction with normative and distributive implications (Desan 2014; Aglietta 2018). It is this institutional side of money which also harbors, as Klein rightfully claims, its democratization potential. But this claim does not have to be made against Habermas; it can be elaborated in Habermasian terms as well. This means that, conceptually speaking, money may end up in a similar position 'between system and lifeworld' as law did before (Habermas 1987; 1996).

\section{The different roles of law in European market vs monetary integration}

Bringing the discussion to the European context, we would like to emphasize the distinction between market and monetary integration. As indicated above, the role assigned to law in these two substantive spheres of integration differs. While in market integration law is "both the object and agent" of the integration process (Dehousse and Weiler 1990, 243), the role of law in Europe's Economic and Monetary Union (EMU) consists in establishing the constitutional framework for monetary integration.

Before we elaborate on the implications of this important distinction, some remarks are due on the different timing of market and monetary integration. Although monetary cooperation started right after the end of the Bretton Woods monetary system, it was only fully developed in the Maastricht Treaty (1992). Approaching European integration from this dynamic perspective allows conceiving market and monetary integration as different but overlapping processes encapsulated into a single institutional framework. Accordingly, their institutional implementation is intertwined in such a way that new institutions formed for 
the purpose of monetary integration (the ECB) coexist with institutions created with the objective of achieving market integration (the Commission, the European Parliament, the Council and the Court). Furthermore, market and monetary integration came to be embedded in a single legal framework originally established for and developed according to the principles and needs of market integration. Whereas in market integration the purpose of law is to constrain political power in order to enable market creation, by proceeding to monetary integration law establishes a (discretionary) public power able to deal with questions of economic policy and to address particulars of economic events (cf. Klein 2020a, 7). Hence, to obtain a complete picture of the state of European integration today requires merging two perspectives: one highlighting the political implications of the introduction of a single currency, anticipated by Hayek (Klein 2020a, 2), the other pointing out the features of a legal order ill-suited to macroeconomic integration. Frictions and conflicts between the constitutional role of law in monetary integration and the more substantive role played by law in market integration result from this cumulative design (Losada 2020a).

\section{III.1 Market integration through law: establishing a community of law}

According to what is a commonplace in European studies, law plays a critical role in European integration: not only through the law-making procedures established in the Treaties (known as the Community method), but also and in particular through the decisive role of the Court of Justice's jurisdiction. With its prointegrative interpretation of the provisions of the Treaties and secondary law, especially in the formative years of the European legal order (the doctrines of direct effect and primacy) and the following decades of consolidation of the European polity (protection of fundamental rights, democratic and rule-based community of law), the Court has reinforced commitment to the rational authority of law as a mechanism of integration.

The relationship between law, legitimacy, and democracy in market integration has been thoroughly studied (Weiler 1991; Scharpf 1999). The European legal order is composed of primary law (the European Treaties) and secondary law (legal acts adopted according to the procedures described in the Treaties). Primary law has been established in accordance with the requirements of national constitutions. We can thus assume that from a national constitutional point of view the democratic credentials of EU law and the legitimacy of the EU political system are beyond doubt. The assessment of secondary law is more complicated, because this should be by reference to the EU political system established in primary law. This combines the participation of institutions directly elected by European citizens (the European Parliament) with that of other, only indirectly legitimated institutions (the Commission and the Council). In general, the decisionmaking procedures corresponding to each concrete domain of integration depend on the specific combination of the different interests involved in that field (Majone 2005). The participation of the Commission, the European Parliament, and the Council therefore reflects a combination of the various interests they each represent - the general European interest, the interest of European citizens, and the interest of Member States. It seems to us that it was not by chance that precisely since the launch of monetary integration, and in particular during the last decade, the formal procedural path established for adoption of European legislation has given way to more informal procedures. Participation by the three institutions, rather than occurring on a sequential basis only, frequently merges in the form of 'trilogues', where they negotiate together the content of new legislation (Reh 2014; Roederer-Rynning and Greenwood 2017).

An analysis of the specific procedures established for adoption of delegated and implementing acts, whose negotiation relies on a plethora of technical committees, still requires more detail. The members of these 
committees are experts in their specific fields, each appointed by their own Member State. As such, they embody both the national interest and technical expertise in the committee's decision-making procedure. Due to the off-the-radar nature of most of these meetings, technical discussions in committees correspond more to the template of a deliberation rather than a negotiation. Joerges and Neyer (1997) famously characterized these decision-making procedures as an instance of 'deliberative supranationalism', since the final agreement represents a common European interest resulting from deliberation based on technical premises (cf. Joerges 2002). Hence, the legitimacy of this procedure for adoption either of delegated legislation or of normative implementation, rather than being primarily based on the direct democratic legitimation of the participating institutions, results from the deliberative component of the decision-making process. As such, it corresponds to the Habermasian ideal of democratic deliberation.

Consequently, Polanyi's claim that "society would be organized based on the dictates of the market, the messy work of politics avoided", as Klein puts it (2020a, 4), is not fully convincing in European market integration. The involvement of different political interests in the European legislative procedure does not set aside political struggles and clashes at the European Parliament, where direct democratic legitimacy resides. Moreover, in its role as co-legislator the Parliament engages in negotiations with the Council, whose members are indirectly legitimated as national executives. That way, a variety of interests are integrated into legislative decisions. This is particularly true when trilogues are used, because they open the door for deliberation between agents of the Parliament, the Council, and the Commission without affecting their representativeness (Laloux 2021). This deliberative component is even more evident in the case of comitology procedures.

It thus seems justified to claim that market integration has resulted from a political process combining expert knowledge and representation of national interests. Moreover, because of the balance between the legitimacy of the participating institutions and the deliberative character of various legislative processes, market integration did not exclude politics but actually involved a relatively harmonious relationship between law, democracy, and legitimacy. Of course, this is not without flaws, but discontent can be addressed. Changes in the political representation of the polity will result in new laws, which will in turn increase the legitimacy of the political system. Hence, law works as the formal expression of the common will towards (market) integration, which is democratically determined through deliberative procedures.

\section{III.2 Monetary integration and law: the emergence of a community of debt}

Although monetary coordination between Member States' currencies became relevant as soon as the Bretton Woods monetary system collapsed, we only consider monetary integration as such to have taken place with the signature of the Treaty of Maastricht. As is well known, establishing a common currency (the Euro) relied on an asymmetrical institutional design: the conduct of monetary policy was assigned to the newly created ECB, whereas fiscal policies still fall within national competence and should be coordinated to the extent needed to guarantee the stability of the new common currency through the Stability and Growth Pact (SGP) - and later through the European Semester.

Because of the specific features of these new competences, which aim at producing certain (monetary and fiscal) policy results, the role of law in monetary integration significantly differs from the role that law plays in market integration. In market integration, law is both the agent and the object of integration. In pursuing harmonization of legal regimes (a legal objective as such) to promote the single market, both legislative activity at European level and jurisdictional activity by the Court of Justice put law at the center. In contrast, 
law's function with regard to the goals of monetary integration (namely, to guarantee price stability in monetary policy and the stability of the common currency through coordination of national fiscal policies) is purely constitutional. Hence, the major role played by law in monetary integration is to establish the constitutional framework for monetary and fiscal policies.

This difference has important implications. In market integration, law is the by-product of political deliberation. Consequently many different political outcomes can result from the established legislative procedure. In monetary integration, this open-endedness of the political process cannot be presumed. Instead, law is used to petrify a given political agreement that cannot be amended by a new political agreement as expressed through the legislative procedure - only by renewal of the constitutional agreement. The upshot is that while in market integration the imaginative use of law could promote integration (think for instance of the principle of mutual recognition), monetary integration uses law to constrain a number of political options. This also means that the role of the Court in monetary integration is restricted to checking the conformity of political actions with the constraints established in the Treaties. Due to its macroeconomic character, the substantive content of EMU policies is barely justiciable, unless procedural requirements have been ignored or policies have been overtly oriented towards goals manifestly at odds with the objectives established in the Treaties. This rigidity in monetary policy objectives explains the political magnitude of the legal conflict between the CJEU and the German Federal Constitutional Court as to whether the ECB's quantitative easing program (PSPP) is in line with the Treaties.

That said, since fiscal policy is still a competence of Member States the limitations imposed on the European level are mostly linked to safeguarding the common currency. Apart from these specific limits, in principle Member States enjoy great leeway in deciding on their budgets. The institution in charge of monitoring the alignment of national fiscal policies with the common needs resulting from having a single currency is the ECOFIN Council, which consists in national ministers of economy and finance. This is the forum where fiscal policy coordination effectively takes place - and more specifically in the Eurogroup, which refers to the formation representing the Euroarea member states. With the help of the Commission working as a secretariat, Member States can compare best practices, monitor each other's progress against preestablished benchmarks, and advance preferred policies for the Euroarea as a whole through peer pressure. The informal character of the Eurogroup together with the closed-door policy of meetings promotes a form of discussion that has been considered to be of a deliberative nature. Accordingly, some authors have suggested the existence of 'deliberative intergovernmentalism' in monetary integration (Puetter 2006; 2012). However, the role of law in monetary integration differs notably from what could be expected from a political system fully complying with Habermasian deliberative standards.

The following arguments may illustrate this point. On the one hand, the more time passes, the more outdated the original EMU political agreement and the resulting constitutional framework become - something particularly noticeable once circumstances have changed due to unexpected economic developments that resulted in unforeseen economic scenarios. Foundational political decisions agreed in primary law will be increasingly questioned the more the political-economic context changes. On the other hand, a peculiarity of fiscal policy coordination at the European level is that the intended outcome of these discussions is public policies to be implemented at national level. In this context, enforceability is not a matter of law but becomes a political process relying on political pressure from peers and the European Commission (within the context of the European Semester) and, especially, on leaving to financial markets the crucial task of disciplining states implementing unsound policies. What in market integration was a task funneled through law, via private actors' access to the court in case of violation of EU law provisions, here depends on political and 
financial market actors. The rational authority of law, resulting from self-determined commitments, has been replaced by the (ir)rational pressure of markets exogenously imposed on political actors.

A third reason is that since the outcomes of Eurogroup meetings are concrete public policies to be implemented at national level, in principle a subtle incongruence exists between the formal legal procedure for approval of the national budget in the national parliament and the actual content of the budget, heavily influenced by the outcomes of a debate held in a different forum (Ruíz Almendral 2017). The effects of this incongruence for the legitimacy and democratic character of public decisions became evident once the EU, due to a number of crises and institutional developments, imposed conditionality (understood as a clear set of policies to be implemented at national level) on certain Member States in exchange for financial assistance (Viţă 2017). Encapsulated in a technically convoluted and messy skein composed of EU law, international law and even private law, conditionality guarantees that Member States cannot diverge from public policies suggested on the European level. As such, conditionality became a distinctive feature of the new type of community established in post-crisis Europe: a community of debt (Losada 2020b). The price to be paid to participate in this community is losing agency over key budgetary decisions, leading to the hollowing out of democracy and legitimacy (Schmidt 2020) and, subsequently, to the endangering of the rule of law (Kilpatrick 2015; Joerges 2016).

\section{Conclusion: some concrete issues with the law of monetary integration}

As we have shown, the implications of the distinction between market and monetary integration deserve more extensive exploration, especially from a legal point of view. Rather than addressing the role of law in European integration as such, it is illuminating to consider the role that law plays in each of these two dimensions. This more differentiated perspective allows contextualization of some of the ideas presented by Klein and an even deeper understanding of the tensions revealed by applying a Polanyian approach to European integration. Hence, while it may be true that such an approach "challenges the idea, implicit in European law, that economic relationships could be fully constituted by legal norms" (Klein 2020a, 2), this applies, first of all, to the dimension of market integration. However, institutionally speaking, politics is not excluded in this dimension but may enter the law governing the single market through democratic and deliberative procedures. In contrast, European law on monetary integration codifies a specific type of economic relations - creditor-debtor relations - that are also (and mostly) the result of Central Bank policy decisions. The assumption that European law fully constitutes economic relationships is thus an overstatement in reference to monetary integration. At the same time, law's connection with democratic and deliberative processes is also weaker in this dimension in institutional terms. Politics is more openly based on differences of power, for example, between creditor and debtor states.

By the same token, if it is claimed that "[t]he ideal of the single market ends up 'overburdening' law as a vehicle of European integration (...), investing it with political functions that law cannot fulfil" (Klein 2020a, 2 ), then this statement may be correct with regard to market integration, where the link between law, democracy, and legitimacy is still relatively intact. However, it is more challenging to interpret the law of monetary integration in these terms, since the rationalizing potential of law is more confined in this context, and deliberative politics are overshadowed by power politics. A Polanyian analysis of European law, just as well as a Habermasian one, has to take these differences into account, and will only reach its full potential if it considers how the law of market integration and the law of monetary integration differ but also interact in today's European Union. 
Distinguishing between market and monetary integration in relation to European law can thus add relevant nuances to Klein's approach to European integration. We conclude this comment by highlighting a few aspects relevant to Klein's analysis regarding the law of monetary integration and the re-democratization potential of money and labor.

\section{IV.1 The public-private law divide and its role in fictitious commodification}

In his Polanyian approach to European integration and European law, Klein makes "an important and daringly innovative conceptual move" (Joerges 2021, 2). In his reading of Polanyi, the conflict between capitalism and democracy, or the self-regulating market and its social corrective (in the form of non-market institutions, or non-market modes of economic coordination), can be represented as "the conflict between the democratic ideal of political equality and the market ideal of contractual equality" (Klein 2020a, 5). While, for Klein, this seems tantamount to distinguishing legally codified individual freedoms from politically determined collective autonomy, it also easily translates into two spheres of law, private and public: whereas political equality is a matter of public law, contract equality relies on private law. The public-private law divide is much debated in social theories of law, including Habermas's discourse theory of law. Habermas $(1996,104)$ emphasizes the "co-originality of private and public autonomy", which forms the centerpiece of his argument on the system of rights. The normative implication is that in order to preserve the link between legality and legitimacy, private autonomy (as expressed in private law) and public autonomy (as expressed in public law) have to be given equal weight.

The distinction between private and public law is also relevant for the process of commodification of land, labor and money, as recently explained by Pistor (2019a; 2019b). In a nutshell, her argument is that contractual parties, through their autonomy to determine the terms and content of a contract, took advantage of certain features of public law to shield the value assigned to fictitious commodities. Hence, private law contributed to commodification by relying on state power (and thus on the public authority representing the democratic claim of political equality) to guarantee liquidity of capital in the long term. Although a regulatory approach can in principle contain the commodification implied by such private lawbased practices, Pistor's historical account explains how - due to the predominance of private law in Common law systems and to the current ability to choose jurisdiction in a globalized world (forum shopping) - fictitious commodities are mostly ruled by private law.

European monetary integration and, in particular, developments following the debt crisis in the Eurozone, pushed this historical trend one step forward. The subjects of private law here include collective actors such as states and international institutions. In order to guarantee full repayment of financial assistance provided to Member States in distress, private agreements of a quasi-contractual nature were drafted between European and international institutions (creditors) and the Member State in question (debtor). These private agreements, signed in the form of Memoranda of Understanding (MoU), included specific economic policy measures to be adopted by the debtor. Although the private law rationale would suggest that, as private agreements, these MoUs would be based on equality between the parties, the very opposite is true: the European Treaties (public law) guarantee equality between Member States, whereas the conditionality agreements were conceived as a way to circumvent the Treaties and the principle of formal equality they recognize.

Instead, the relation between the contractual parties was adjusted according to a different rationale: the difference in economic power, which in the case of debtor states results from the need for financial assistance 
(Losada 2017). This explains why, even though the actors involved include Member States and European institutions, these contracts are not governed by EU law. What this demonstrates is that the 'Common law approach' privileging private law can be reinforced even at the expense of the sovereign: the state power in Pistor's terms. If according to her reconstruction Common law has helped to circumvent regulatory obstacles by relying on state power to enforce contracts, this new step relies on state power to deactivate even sovereign powers (as sovereigns are parties to the contracts). The use of private law is brought here to a meta-level where it regulates public actors' discretion through contracts whose enforceability ultimately relies on their own sovereign powers.

\section{IV.2 Trade unions and central banking as counterforces of commodification}

The focus of Klein's reconstruction of the fault lines of European integration in Polanyian terms is based on the fictitious commodities of labor and money. If market orders further the commodification of labor and money and European law promotes market integration, then European law furthers rather than limits the commodification of labor and money. We have already emphasized that this reasoning lacks nuances both with regard to the law of market integration (which can still resort to various sources of legitimacy) and the law of monetary integration (which is relatively disconnected from rationalizing processes). In the present context, we focus on what Klein $(2020 a, 11)$ thinks are the implications of the project of integration through law for the commodification of labor and money.

Drawing on the distinction between market and monetary integration, which we elaborated upon above, it first has to be noted that although both labor and money are indeed commodified through law, only the commodification of labor results from the process of integration through law. In European integration the commodification of money was triggered by a political agreement between Member States on the liberalization of capital movements within the EU, subsequently introduced into primary law (although expanding its scope towards third countries as well) as part of the overall constitutional design for monetary integration (EMU). It was thus a project driven and led by political will, and only articulated by legal means: in this case, law was not the 'mask and shield' of a hidden political strategy (Burley and Mattli 1993), as is usually implied by integration through law. Only when the Treaties had recognized the free movement of capital were the dynamics of integration through law set in motion, and the Court could finally play an active role in the process of commodification of money.

Moreover, some remarks are also due regarding Klein's reconceptualization of trade unions and central banking as re-democratizing instruments overcoming the commodification of labor and money, respectively. Again, the fact that the law behind these false commodities stems from two different layers of the European integration process - market vs. monetary integration - plays a role. Moreover, the interplay between national and European levels of economic organization also has practical consequences, which we do not find fully addressed in Klein's approach. To us it seems that Klein conceives of alternative modes of economic coordination, which reflect Polanyi's categories of reciprocity, redistribution, exchange, and householding, either in the abstract or from a merely national point of view. This results in considering trade unions as examples of reciprocity - at least as long as they are based on inter-sectoral bargaining (Klein 2020a, 5). However, the picture is much more complicated when not only the sectoral/inter-sectoral dimension is involved, but also the national/European dimension is taken into account. Under market integration, trade unions compete between themselves along national lines. This has indeed become more accentuated through monetary integration, creating creditor and debtor Member States based on cumulative institutionalizations of debt relations (Losada 2020a). Accordingly, in the 2000s German trade unions 
accepted and promoted wage contention, if not contraction, in order to compete against other peripheral economies (Rathgeb and Tassinari forthcoming). In this regard, it is more difficult to apply Klein's reading of Polanyi, namely that labor movements lead to reciprocal coordinating institutions. This may only be true within national borders.

A similar claim can be made regarding the re-democratizing potential of central bank decisions in relation to commodified money. Due to the very premise on which the EMU was built, a single currency with a centralized monetary policy coexists with national fiscal policies. This means that a single monetary policy has to be applied to different national contexts - except in an emergency scenario where all Member States are in a similar situation and claims are not contested (as is the case with the covid-19 situation). To achieve the re-democratization of money, monetary policy has to respond to the varying needs and different situations of each particular economic context. In contrast, the task of the ECB is to target its monetary policy to the Union as a whole. Hence, in Europe, monetary policy gets decontextualized and requires each Member State to accept sub-optimal policy outcomes. Without a proper democratic discussion of the adequacy of monetary policy measures for the overall European context, this model of central banking only incites interpretation of monetary policy outcomes according to national interests and consequently according to the division between creditor and debtor states within the Union.

The upshot is that the potential of trade unions and central banking to act as correctives for the commodification of money and labor, as Klein's reading of Polanyi suggests, cannot be realized in the European Union for parallel reasons (although they work in opposite directions). Whereas market integration, especially if combined with monetary integration, forces trade unions to confine their discourse within the national context against fellow workers from other Member States, monetary integration creates a single monetary policy to address different national needs. The disconnection between European and national levels - particularly acute since establishment of the euro - only adds to the problematic role of law as a constitutional framework in monetary integration and the subordination of democratic and legitimacy considerations in this respect. Consequently, despite theoretically promising, at the current stage of European integration the re-democratization potential of trade unions and central banks is a vain hope. This pessimistic assessment also applies to European level collective agreements, which could have been a way out of this stalemate: by integrating workers' voices across borders, a more systematic response to inefficient monetary policy could have been obtained. However, despite the Commission's suggestion to promote and encourage such European level collective agreements (European Commission 2001) the initiative still leaves wide room for improvement. At present, it seems that the chances to strike a new balance between money and labor in EMU are few.

\section{REFERENCES}

Aglietta, Michel. 2018. Money: 5000 Years of Debt and Power. London: Verso.

Beckert, Jens. 2009. "Wirtschaftssoziologie als Gesellschaftstheorie." Zeitschrift für Soziologie 38 (3): 182197. https://doi.org/10.1515/zfsoz-2009-0301 
Burley, Anne-Marie, and Mattli, Walter. 1993. "Europe Before the Court: A Political Theory of Legal Integration." International Organization 47 (1): 41-76. https://doi.org/10.1017/\$0020818300004707

Commons, John R., 1924. Legal Foundations of Capitalism. New York: The Macmillan Company.

Dehousse, Renaud, and Weiler, Joseph H. H. 1990. "The Legal Dimension." In The Dynamics of European Integration, edited by William Wallace, 242-260. London: Pinter Publishers.

Desan, Christine. 2014. Making Money: Coin, Currency, and the Coming of Capitalism. Oxford: Oxford University Press.

Ebner, Alexander. 2015. "Marketization: Theoretical Reflections Building on the Perspectives of Polanyi and Habermas." Review of Political Economy 27 (3): 369-389. https://doi.org/10.1080/09538259.2015.1072315

European Commission. 2001. European Governance: a White Paper [COM(2001) 428 final]. https://op.europa.eu/en/publication-detail/-/publication/11c3e337-9cf5-4603-a518-cacb77207e3b

Frerichs, Sabine. 2016. "The Law of Market Society: A Sociology of International Economic Law and Beyond" In Finnish Yearbook of International Law 2012/2013, vol. 23, edited by Jarna Petman, 173-237. Oxford: Hart Publishing.

Frerichs, Sabine, 2019. "Karl Polanyi and the Law of Market Society." Österreichische Zeitschrift für Soziologie 44 (2): 197-208. https://doi.org/10.1007/s11614-019-00328-5

Frerichs, Sabine, and Losada, Fernando. Forthcoming. "European Integration Through Law and Its Limits." In Sociology of Europeanization, edited by Sebastian Büttner, Monika Eigmüller, and Susann Worschech, Susann. Berlin: De Gruyter.

Habermas, Jürgen. 1987. The Theory of Communicative Action, Vol. 2. Lifeworld and System: A Critique of Functionalist Reason. Boston: Beacon Press.

Habermas, Jürgen. 1996. Between Facts and Norms: Contributions to a Discourse Theory of Law and Democracy. Cambridge: MIT Press.

Hann, Chris. 2010. "Moral Economy" In The Human Economy edited by Keith Hart, Jean-Louis Laville and Antonio D. Cattani, 187-196. Cambridge: Polity Press.

Hart, Herbert L. A. 1961. The Concept of Law. Oxford: Clarendon Press.

Hart, Keith. 1986. "Heads or Tails? Two Sides of the Coin." Man London (New Series) 21 (4): 637-656. https://doi.org/10.2307/2802901

Hesselink, Martijn W. 2010. "A Spontaneous Order for Europe? Why Hayek's Libertarianism is Not the Right Way Forward for European Private Law" In European Private Law After the Common Frame of Reference, edited by Hans W. Micklitz and Fabrizio Cafaggi, 123-146. Cheltenham: Edward Elgar.

Jessop, Bob, and Sum, Ngai-Ling. 2019. "Polanyi: Classical Moral Economist or Pioneer Cultural Political Economist?" Österreichische Zeitschrift für Soziologie 44 (2): 153-167. https://doi.org/10.1007/s11614-019$\underline{00338-3}$ 
Joerges, Christian. 2002. "Deliberative Supranationalism - Two Defences." European Law Journal 8 (1): 133151. https://doi.org/10.1111/1468-0386.00145

Joerges, Christian. 2011. "The Idea of a Three-dimensional Conflicts Law as Constitutional Form" In Constitutionalism, Multilevel Trade Governance and International Economic Law, edited by Christian Joerges and Ernst- Ulrich Petersmann, 413-445. Oxford: Hart.

Joerges, Christian. 2016. "Integration Through Law and the Crisis of Law in Europe's Emergency" In The End of the Eurocrats' Dream: Adjusting to European Diversity, edited by Damian Chalmers, Markus Jachtenfuchs, and Christian Joerges, 299-338. Cambridge University Press.

Joerges, Christian. 2021. "Responding to Socioeconomic Diversity in the European Union (and to Steven Klein's Essay) with Democracy-Enhancing Conflicts Law." Global Perspectives 2 (1): 1-8.

https://doi.org/10.1525/gp.2021.18788

Joerges, Christian, and Falke, Josef, eds. 2011. Karl Polanyi, Globalisation and the Potential of Law in Transnational Markets. Oxford: Hart.

Joerges, Christian, and Kreuder-Sonnen, Christian. 2017. "European Studies and the European Crisis: Legal and Political Science between Critique and Complacency." European Law Journal 23 (1-2): 118-139. https://doi.org/10.1111/eulj.12225

Joerges, Christian, and Neyer, Jürgen. 1997. "From Intergovernmental Bargaining to Deliberative Political Processes: The Constitutionalisation of Comitology." European Law Journal 3 (3): 273-299.

https://doi.org/10.1111/1468-0386.00031

Joerges, Christian, Stråth, Bo, and Wagner Peter, eds. 2005. Economy as a Polity: The Political Constitution of Contemporary Capitalism. London: UCL Press.

Kelsen, Hans. 2002. "On the Borders Between Legal and Sociological Method" in Weimar: A Jurisprudence of Crisis, edited by Arthur Jacobsen and Bernhard Schlink. Berkeley: University of California Press.

Kilpatrick, Claire. 2015. "On the Rule of Law and Economic Emergency: The Degradation of Basic Legal Values in Europe's Bailouts." Oxford Journal of Legal Studies 35 (2): 325-353.

https://doi.org/10.1093/ojls/gqv002

Klein, Steven. 2020a. "European Law and the Dilemmas of Democratic Capitalism." Global Perspectives 1 (1): 1-16. https://doi.org/10.1525/gp.2020.13378

Klein, Steven. 2020b. "The Power of Money: Critical Theory, Capitalism, and the Politics of Debt." Constellations 27 (1): 19-35. https://doi.org/10.1111/1467-8675.12448

Laloux, Thomas. 2021. "Agency slack as cause of deviation in trilogue negotiations." Journal of European Public Policy 28 (1): 132-151. https://doi.org/10.1080/13501763.2020.1859595

Lockwood, David. 1992. "Appendix: Social Integration and System Integration" In Solidarity and Schism: 'The Problem of Disorder' in Durkheimian and Marxist Sociology, 399-412. Oxford: Clarendon Press.

Losada, Fernando. 2017. "Institutional implications of the rise of a debt-based monetary regime in Europe." European Law Journal 22 (6): 822-837. https://doi.org/10.1111/eulj.12223 
Losada, Fernando. 2020a. "On European Macroeconomic Integration and the Ensuing Clash of Courts: Apropos the German Constitutional Court Ruling on the ECB's Public Sector Purchase Program." Ordines 6 (1): 58-66. http://www.ordines.it/wp-content/uploads/2020/10/Losada.pdf

Losada, Fernando. 2020b. "A Europe of Creditors and Debtors: Three Orders of Debt Relations in European Integration." Journal of Common Market Studies 58 (4): 787-802. https://doi.org/10.1111/icms.12988

Majone, Giandomenico. 2005. Dilemmas of European Integration: The Ambiguities and Pitfalls of Integration by Stealth. Oxford University Press.

Olofsson, Gunnar. 1995. “Embeddedness and Integration: An Essay on Karl Polanyi's 'The Great Transformation" In Social Integration and Marginalisation, edited by Nils Mortensen, 72-113. Köpenhamn: Samfundslitteratur.

Pistor, Katharina. 2019a. The Code of Capital: How the Law Creates Wealth and Inequality. Princeton: Princeton University Press.

Pistor, Katharina. 2019b. “Capital's Global Rule.” Constellations 26 (3): 430-441.

https://doi.org/10.1111/1467-8675.12434

Polanyi, Karl. 1957a. "The Economy as Instituted Process." In Trade and Market in the Early Empires: Economies in History and Theory edited by Karl Polanyi, Conrad M. Arensberg, and Harry W. Pearson, 24370. Chicago: Henry Regnery Company.

Polanyi, Karl. (1944) 1957b. The Great Transformation: The Political and Economic Origins of our Time. Boston: Beacon Press.

Puetter, Uwe. 2006. The Eurogroup: How a Secretive Circle of Finance Ministers Shape European Economic Governance. Manchester: Manchester University Press.

Puetter, Uwe. 2012. "Europe's deliberative Intergovernmentalism: the role of the Council and European Council in EU economic governance." Journal of European Public Policy 19 (2): 161-178.

https://doi.org/10.1080/13501763.2011.609743

Rathgeb, Philip and Tassinari, Arianna. Forthcoming. "How the Eurozone disempowers trade unions: the political economy of competitive internal devaluation." Socio-Economic Review.

https://doi.org/10.1093/ser/mwaa021

Reh, Christine. 2014. "Is informal politics undemocratic? Trilogues, early agreements and the selection model of representation." Journal of European Public Policy 21 (6): 822-841.

https://doi.org/10.1080/13501763.2014.910247

Roederer-Rynning, Christilla and Greenwood, Justin. 2017. "The European Parliament as a developing legislature: coming of age in trilogues?" Journal of European Public Policy 24 (5): 735-754.

https://doi.org/10.1080/13501763.2016.1184297

Ruíz Almendral, Violeta. 2017. "The European Fiscal Consolidation Legal Framework: Its Impact on National Fiscal Constitutions and Parliamentary Democracy." In Constitutional Change through Euro-crisis Law edited by Thomas Beukkers, Bruno De Witte, and Claire Kilpatrick, 27-67. Cambridge: Cambridge University Press.

Saiag, Hadrien. 2014. "Towards a Neo-Polanyian Approach to Money: Integrating the Concept of Debt." Economy and Society 43 (4): 559-581. https://doi.org/10.1080/03085147.2014.898825 
Scharpf, Fritz W. 1999. Governing in Europe: Effective and Democratic? Oxford: Oxford University Press.

Schmidt, Vivien A. 2020. Europe's Crisis of Legitimacy: Governing by Rules and Ruling by Numbers in the Eurozone. Oxford: Oxford University Press.

Sum, Ngai-Ling and Jessop, Bob. 2013. Towards a Cultural Political Economy: Putting Culture in its Place in Political Economy. Cheltenham: Edward Elgar Publishing.

Thompson, Edward P. 1991. Customs in Common. London: Merlin Press.

Thompson, Edwards P. 1971. "The Moral Economy of the English Crowd in the Eighteenth Century." Past \& Present 50 (1): 76-136. https://doi.org/10.1093/past/50.1.76

Viţă, Viorica. 2017. "Revisiting the Dominant Discourse on Conditionality in the EU: The Case of EU Spending Conditionality." Cambridge Yearbook of European Legal Studies 19: 116-143. https://doi.org/10.1017/cel.2017.4

Weber, Max. 1949. "Objectivity in Social Science and Social Policy" In The Methodology of Social Sciences, 49-112. Glencoe: Free Press, 1949.

Weiler, Joseph H. 1991. "The Transformation of Europe." Yale Law Journal 100 (8): 2403-2483. https://digitalcommons.law.yale.edu/yli/vol100/iss8/5/ 